\title{
Economic feasibility of Gluconacetobacter diazotrophicus in carrot cultivation
}

\author{
Nelson Ceballos-Aguirre ${ }^{1 *(\mathbb{D}}$, Gloria María Restrepo², Alejandro Hurtado-Salazar ${ }^{3}$, \\ Jorge Andrés Cuellar ${ }^{4}$ Óscar Julián Sánchez ${ }^{5}$
}

10.1590/0034-737X202269010006

\begin{abstract}
The inclusion of more sustainable alternatives such as bacterial inoculants is a viable option for the competitiveness of vegetable crops in tropical countries such as Colombia. The economic feasibility of a bacterial suspension of $G$. diazotrophicus applied to the carrot crop was determined. The native isolate G. diazotrophicus GIBI029 was evaluated and the strain ATCC 49037 was used as a control. The experiment was installed in a subdivided plot design, where the plot was the bacterium G. diazotrophicus (ATCC49037 and GIBI029. The subplot was the concentration of G. diazotrophicus $\left(88 \times 10^{6} \mathrm{CFU} / \mathrm{mL}\right.$ and $\left.18 \times 10^{7} \mathrm{CFU} / \mathrm{mL}\right)$ and, in it, the levels of nitrogen and phosphorus ( $0 \%$ and $100 \%$ nitrogen and phosphorus) were assorted. The average weight of the carrot (g) and the yield by quality of the consuming organ ( $\mathrm{kg} /$ ha) were evaluated. Through the production cycle, fixed, variable, and total costs were calculated. Benefit / cost ratios higher than 1.46 and net income up to US $\$ 10,817 /$ ha were achieved. It is possible to efficiently and economically use the native isolate $G$. diazotrophicus GIBI029 in the search for more sustainable and competitive cultural practices.
\end{abstract}

Keywords: diazotrophic bacteria; plant growth promoter; benefit / cost ratio.

\section{INTRODUCTION}

The carrot is one of the most consumed vegetables worldwide. The world production of carrots reached $39,996,287 \mathrm{t}$ in 2018 , corresponding to a total cultivated area of 1,131,049 ha (Faostat, 2020). Carrot production in Colombia is very expensive due to the high price of fertilizers: approximately $25 \%$ of the total costs are destined to the nutrition of the crop.

In the case of carrot cultivation, the Colombian farmer cannot compete with foreign producers, since imports of this vegetable present reduced purchase charges and have low product distribution tariffs. In general, the Colombian agricultural sector is unaware of the use of new, cheaper fertilization strategies such as the use of biofertilizers, which could affect the final marketing price.

The development of biofertilizers traditionally focused on the production of Rhizobium for its application in legume crops, especially soybeans; however, other alternatives are currently being explored through the development of inoculants based on autochthonous nitrogen-fixing bacteria such as those of the genera Herbaspirillum and Gluconacetobacter.

In particular, the bacterium G. diazotrophicus exhibits important properties to promote plant growth, as has been demonstrated by Beneduzi et al. (2013) and in a previous work (Restrepo et al., 2017). G. diazotrophicus has the potential to provide the farmer with benefits such as the production of phytohormones of both auxins and gibberellins in significant quantities to allow an efficient and profitable growth system (Figueroa-Viramontes et al., 2011). Additionally, it has been detected in grass plants that these microorganisms have the ability to naturally solubilize micronutrients such as phosphorus, zinc, iron, potassium, and magnesium (Eshaghi et al., 2019). This solubilization property is especially important in the case of phosphorus, since although high amounts

\footnotetext{
Submitted on December $2^{\text {nd }}, 2020$ and accepted on June $25^{\text {th }}, 2021$.

'Departamento de Producción Agropecuaria, Universidad de Caldas, Manizales, Caldas, Colombia. nelson.ceballos@ucaldas.edu.co

2Instituto de Investigación en Microbiología y Biotecnología, Universidad Católica de Manizales, Manizales, Caldas, Colombia. grestrepo@ucm.edu.co

Departamento de Agronomía, Universidad de Pamplona, Pamplona, Norte de Santander, Colombia. alhuza@gmail.com

${ }^{4}$ Departamento de Ciencias Biológicas, Universidad Autónoma de Manizales, Manizales, Caldas, Colombia. jorgeacuellarg@autonoma.edu.co

5 Departamento de Ingenierías, Universidad de Caldas, Manizales, Caldas, Colombia. osanchez@ucaldas.edu.co

*Corresponding author: nelson.ceballos@ucaldas.edu.co
} 
of phosphorous fertilizers are applied to cultivable soils in the world, a large part of this micronutrient is fixed or immobilized in the soil, preventing its assimilation by plants (Santos et al., 2019; Paredes-Villanueva et al., 2020; Vejan et al., 2016). Precisely, G. diazotrophicus exhibits a significant capacity to solubilize phosphates (Restrepo et al., 2017), which represents an important characteristic for a wide range of economically important crops.

Evaluations of native isolates of $G$. diazotrophicus have been carried out in various crops such as sugar cane (Ferreira et al., 2019), cassava and papaya (Dibut et al., 2010), and tomato (Fernández-Delgado et al., 2019), which have shown a positive effect on growth promotion, making it possible to reduce the use of chemical fertilizers. However, no published articles were found in the available literature on the evaluation of growth promotion by $G$. diazotrophicus in carrot crops. Nevertheless, the economic analysis of the possibility of implementing a technological package that includes the use of this bacterium for the fertilization of carrot crops has not been carried out so far. Consequently, the present investigation aimed at determining the economic feasibility of using a bacterial suspension of $G$. diazotrophicus in promoting carrot growth.

\section{MATERIALS AND METHODS}

\section{Location}

This study was carried out at the Tesorito Farm of the University of Caldas at an altitude of 2,340 masl ( $5^{\circ} 01^{\prime} 49^{\prime \prime} \mathrm{N}$ and $-75^{\circ} 26^{\prime} 13^{\prime \prime} \mathrm{W}$ ), annual rainfall of $1,800 \mathrm{~mm}$, relative humidity of $78 \%$, solar brightness of 1,215 h-light per year, average temperature of $17.5^{\circ} \mathrm{C}$ and sandy loam type of soil (Universidad de Caldas, 2014).

\section{Microorganism}

The native isolate of the bacterium $G$. diazotrophicus GIBI029 from sugar cane was evaluated. The standard strain G. diazotrophicus ATCC 49037 was used as a control of the experiments. The native bacterial isolate come from the Microorganisms Collection of the Universidad Católica de Manizales and are covered by the Permit for the Collection of Wild Specimens of Biological Diversity Framework for non-commercial scientific research purposes No. 1166, issued by the Environmental Authority of Environmental Licenses of Colombia (ANLA) to the Universidad de Caldas.

\section{Preparation of G. diazotrophicus cell suspension}

The preparation of the inoculum and bacterial suspension of $G$. diazotrophicus was carried out using the modified DYGS (Silva et al., 2016) and LGI-PN (Sadeghi $\&$ Khodakaramian, 2020) media. The media were inoculated and incubated at $30^{\circ} \mathrm{C}$ under constant shaking at $150 \mathrm{rpm}$ for 7 days and were evaluated daily until reaching each of the required bacterial concentrations $\left(88 \times 10^{6}\right.$ and $18 \times 10^{7} \mathrm{CFU} / \mathrm{mL}$ ). During this period, the purity, viability, and concentration of the bacteria were verified through the technique of Colony Forming Units per milliliter (Ahmad et al., 2016).

\section{Experimental design}

An experimental design of sub-subdivided plots was used. The largest plot was made up of the bacterium $G$. diazotrophicus (ATCC49037 strain and GIBI029 isolate), and the following bacterial concentrations were arranged in the subplots: $88 \times 10^{6} \mathrm{CFU} / \mathrm{mL}$ and $18 \times 10^{7} \mathrm{CFU} / \mathrm{mL}$ (Restrepo, 2014). In the subplots, the nitrogen and phosphorus levels were assorted in two combinations: With and without the joint addition of nitrogen and phosphorus ( $0 \%$ and $100 \%$ of nitrogen and phosphorus). Nitrogen fertilization consisted of the addition of $200 \mathrm{~kg} / \mathrm{ha}$ urea while phosphorous fertilization consisted of the addition of $1000 \mathrm{~mL} /$ ha phosphoric acid. In all cases, $120 \mathrm{~kg} / \mathrm{ha} \mathrm{KCl}$ and $80 \mathrm{~kg} / \mathrm{ha} \mathrm{MgSO}_{4}$ were added. The number of replicas per combination was 4 blocks. The experimental unit was $12.3 \mathrm{~m} 2$. In each experimental unit (block) a minimum of 70 carrot plants will be guaranteed. The combinations of the treatments and their coding are presented in Table 1. The variables evaluated to know the effect of the application of G. diazotrophicus in carrot plants were average carrot weight (in g) and yield ( $\mathrm{kg} / \mathrm{ha}$ ), taking into account the qualities according to the weight reached by the consuming organ. The quality grades of the carrot crop consumption organ were defined according to the following classification: Extra quality, greater than $120 \mathrm{~g}$; first quality, 90-119 g; second quality, 70-89 g; third quality, 30-69 g; less than $30 \mathrm{~g}$, lower quality equivalent to losses) (Szel1'g-Sikora et al., 2019).

\section{In-field establishment of treatments}

The establishment and management of the culture was carried out according to the protocols described by SzelagSikora et al. (2019). Ten days after sowing (days), it was applied to each experimental unit or plot, with the corresponding treatment in foliar spray at the inoculated rate of $200 \mathrm{~mL}$ of bacterial suspension according to the treatments and concentrations described in the experimental design.

\section{Evaluation of economic feasibility}

The economic feasibility was assessed through individual calculation applying the feasibility analysis approach reported by Herrera et al. (2016). The value of the $G$. diazotrophicus suspension was estimated at a value of 231 US dollars (US\$), corresponding to the commercial value of a liquid inoculant of the bacterium in one-liter presentation (ATCC, 2020). Likewise, the costs of the different types of fertilization according to the established 
treatments were taken into account. To carry out the economic analysis, the formats adopted by the Corporación Colombia Internacional and DANE (DANE, 2017) were taken into account. The average value of carrots was estimated for the last 10 years (2010-2020) (Corabastos, 2020). The average commercial value was US $\$ 0.34 / \mathrm{kg}$, discriminated as follows: extra US $\$ 0.49 / \mathrm{kg}$, first US $\$ 0.43 /$ $\mathrm{kg}$, second US $\$ 0.26 / \mathrm{kg}$, and third US $\$ 0.20 / \mathrm{kg}$ (Corabastos, 2020). Finally, the following financial indicators were calculated according to Arbelaez et al. (2016): Gross and net income, direct, indirect and total production costs, unit production margin (UPM), and benefit/cost ratio (B/C R). Analysis of variance and Duncan's test were performed considering a $p$-value $<0.05$. For this, the GLM program of SAS version 9.1 (SAS Institute, Inc., USA) was used.

\section{RESULTS AND DISCUSSION}

In the evaluation of the yields, statistically significant differences ( $p \mathrm{dH}$ 0.05) were observed between the different treatments (Tables 1 and 2). In all cases, the application of the high level of concentration $\left(d 2=18 \times 10^{7}\right.$ $\mathrm{CFU} / \mathrm{mL}$ ) of the evaluated bacterial suspensions showed yields higher than $30,345 \mathrm{~kg} / \mathrm{ha}$, as in the case of treatment with the standard ATCC strain with $100 \%$ fertilization (see treatment ATCC- $d 2-100 \mathrm{NP}$ in Table 1) that was above the absolute control without the addition of nitrogenous and phosphorous fertilizers (Control-0NP) and the commercial control to which was applied $100 \%$ of this type of fertilization (Control-100NP).

For the native isolation at the $d 2$ concentration with or without the addition of nitrogenous and phosphate fertilizers, yields not showing statistically significant differences were obtained compared to that achieved with the ATCC 49037 strain applied with this same concentration with $0 \%$ fertilization. This latter treatment exhibited the highest yield of those evaluated in this work $(37,867 \mathrm{~kg} /$ ha). With the values reached, the national average carrot yield $(27,170 \mathrm{~kg} / \mathrm{ha})$ and the average yield in the department (administrative division in Colombia equivalent to a province) of Caldas $(14,500 \mathrm{~kg} / \mathrm{ha}$ ) were exceeded for the year 2017 (Agronet, 2020). These data indicate an added value of approximately $15,000 \mathrm{~kg} / \mathrm{ha}$.

The greatest losses in harvest of the consuming organ were presented in the treatments with the low level of the application concentrations of the bacterial suspensions $\left(d l=88 \times 10^{6} \mathrm{CFU} / \mathrm{mL}\right.$ ) for both strain types (see last column in Table 1). The treatment that used the native isolate of $G$. diazotrophicus at a low concentration without application of additional fertilization presented the lowest performance of those evaluated and presented statistically significant differences $(p<0.05)$ with respect to the treatment with the highest value of performance (coded as ATCC- $d 2-0 \mathrm{NP}$ ) as observed in Table 1.

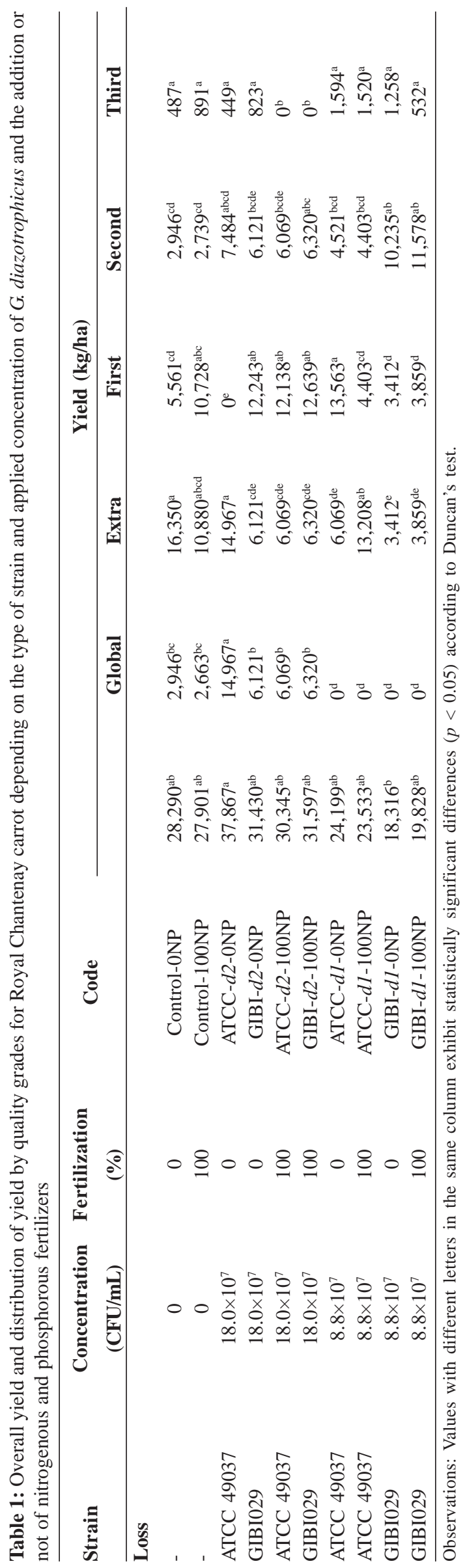


Table 2: Structure of production costs (in US\$/ha) of the Royal Chantenay variety of the carrot crop with the application of G. diazotrophicus as growth promoter

\begin{tabular}{|c|c|c|c|c|c|c|c|c|c|c|}
\hline \multirow{2}{*}{$\begin{array}{l}\text { Treatment } \\
\text { Concept } \\
\end{array}$} & \multicolumn{2}{|c|}{ Control-0NP } & \multicolumn{2}{|c|}{ Control-100NP } & \multicolumn{2}{|c|}{ ATCC-d2-0NP } & \multicolumn{2}{|c|}{ GIBI- $d 2-0 \mathrm{NP}$} & \multicolumn{2}{|c|}{ ATCC- $d 2-100 \mathrm{NP}$} \\
\hline & Total value & $\%$ share & Total value & $\%$ share & Total value & $\%$ share & Total value & $\%$ share & Total value & \% share \\
\hline A. Labor $(1+2+3+4)$ & 1,296 & 35.54 & 1,296 & 32.71 & 1,871 & 42.62 & 1,553 & 38.14 & 1,499 & 34.59 \\
\hline (1) Land adaptation & 241 & 6.61 & 241 & 6.08 & 440 & 10.01 & 365 & 8.96 & 352 & 8.13 \\
\hline Preparation and sowing & 241 & 6.61 & 241 & 6.08 & 327 & 7.45 & 271 & 6.66 & 262 & 6.04 \\
\hline Application of the bacteria to the sowing & 0 & 0.00 & 0 & 0.00 & 113 & 2.57 & 94 & 2.30 & 90 & 2.08 \\
\hline (2) Crop maintenance & 407 & 11.16 & 407 & 10.27 & 552 & 12.58 & 458 & 11.26 & 443 & 10.21 \\
\hline Cultivation work & 299 & 8.20 & 299 & 7.55 & 406 & 9.24 & 337 & 8.27 & 325 & 7.50 \\
\hline Application of inputs & 108 & 2.96 & 108 & 2.73 & 147 & 3.34 & 122 & 2.99 & 117 & 2.71 \\
\hline (3) Harvest & 482 & 13.21 & 482 & 12.16 & 654 & 14.89 & 543 & 13.32 & 524 & 12.09 \\
\hline (4) Post-harvest & 166 & 4.56 & 166 & 4.19 & 225 & 5.13 & 187 & 4.59 & 181 & 4.17 \\
\hline B. Inputs $(5+6+7+8+9+10+11+12+13+14)$ & 1,825 & 50.07 & 2,141 & 54.06 & 1,995 & 45.44 & 1,995 & 48.99 & 2,311 & 53.31 \\
\hline (5) Seed & 599 & 16.44 & 599 & 15.13 & 599 & 13.65 & 599 & 14.72 & 599 & 13.83 \\
\hline (6) Amendment & 29 & 0.79 & 29 & 0.73 & 29 & 0.66 & 29 & 0.71 & 29 & 0.67 \\
\hline (7) Organic fertilizer & 191 & 5.25 & 191 & 4.83 & 191 & 4.36 & 191 & 4.70 & 191 & 4.41 \\
\hline (8) Edaphic fertilizer & 292 & 8.00 & 608 & 15.34 & 292 & 6.64 & 292 & 7.16 & 608 & 14.02 \\
\hline (9) G. diazotrophicus suspension & 0 & 0.00 & 0 & 0.00 & 231 & 5.26 & 231 & 5.67 & 231 & 5.32 \\
\hline (10) Fungicide & 41 & 1.11 & 41 & 1.02 & 0 & 0.00 & 0 & 0.00 & 0 & 0.00 \\
\hline (11) Insecticide & 18 & 0.49 & 18 & 0.45 & 0 & 0.00 & 0 & 0.00 & 0 & 0.00 \\
\hline (12) Herbicide & 3 & 0.07 & 3 & 0.07 & 0 & 0.00 & 0 & 0.00 & 0 & 0.00 \\
\hline (13) Package & 327 & 8.96 & 327 & 8.25 & 327 & 7.44 & 327 & 8.02 & 327 & 7.53 \\
\hline (14) Bundle & 327 & 8.96 & 327 & 8.25 & 327 & 7.44 & 327 & 8.02 & 327 & 7.53 \\
\hline Direct cost $(A+B)$ & 3,121 & 85.62 & 3,437 & 86.76 & 3,866 & 88.06 & 3,548 & 87.12 & 3,810 & 87.90 \\
\hline C. Indirect cost $(15+16+17)$ & 524 & 14.38 & 524 & 13.24 & 524 & 11.94 & 524 & 12.88 & 524 & 12.10 \\
\hline (15) Rent & 229 & 6.28 & 229 & 5.78 & 229 & 5.21 & 229 & 5.62 & 229 & 5.28 \\
\hline (16) Administration & 111 & 3.04 & 111 & 2.80 & 111 & 2.52 & 111 & 2.72 & 111 & 2.56 \\
\hline (17) Incidentals & 185 & 5.07 & 185 & 4.66 & 185 & 4.21 & 185 & 4.54 & 185 & 4.26 \\
\hline Total $(A+B+C)$ & 3,645 & 100.00 & 3,961 & 100.00 & 4,390 & 100.00 & 4,072 & 100.00 & 4,335 & 100.00 \\
\hline
\end{tabular}

Remarks: Coding of the treatments are deciphered in Table 1. 
Continuation of Table 2.

Treatment

GIBI-d2-100NP

ATCC-d1-0NP

ATCC-dl-100NP

GIBI-d1-0NP

GIBI- $d 1$-100NP

Total value \% share Total value

$\%$ share Total value

\% shar

Total value \% share

$1,550-35.34$

$1,196 \quad 32.19$

1,163

29.09

905
213

26.43

980

25.68

Preparation and sowing

Application of the bacteria to the sowing

$\begin{array}{cccc}364 & 8.30 & 281 & 7.56 \\ 271 & 6.17 & 209 & 5.62 \\ 93 & 2.13 & 72 & 1.94\end{array}$

(2) Crop maintenance

Cultivation work

Application of inputs

$93 \quad 2.13$

5.62
1.94

$\begin{array}{llll}457 & 10.43 & 353 & 9.50\end{array}$

$\begin{array}{llll}121 & 2.77 & 94 & 2.52\end{array}$

$541 \quad 12.35$

(4) Post-harvest

$187 \quad 4.26$

B. Inputs $(5+6+7+8+9+10+11+12+13+14)$

$2,311 \quad 52.70$

(5) Seed

$\begin{array}{cccc}599 & 13.67 & 599 & 16.13 \\ 29 & 0.66 & 29 & 0.78\end{array}$

$\begin{array}{ccc}144 & 3.88 \\ 70 & 1,995 & 53.70\end{array}$

(6) Amendment

(7) Organic fertilizer

(8) Edaphic fertilizer

203

203
70

$\begin{array}{ccc}29 & 0.66 & 29 \\ 191 & 4.36 & 191\end{array}$

(9) G. diazotrophicus Suspension

(10) Fungicide

$\begin{array}{llll}191 & 4.36 & 191 & 5.15 \\ 608 & 13.86 & 292 & 7.85\end{array}$

0.78
5.15
7.85

$5.26 \quad 231$

(11) Insecticide

(12) Herbicide

(13) Package

$\begin{array}{cccc}0 & 0.00 & 0 & 0.21 \\ 0 & 0.00 & 0 & 0.00\end{array}$

(14) Bundle

$\begin{array}{lll}0.00 & 0 & 0.00\end{array}$

$\begin{array}{lll}0.00 & 0 & 0.00\end{array}$

$\begin{array}{lll}7.45 & 327 & 8.79\end{array}$

Direct cost (A+B)

C. Indirect cost $(15+16+17)$

(15) Rent
(16) Administration
(17) Incidentals

(17) Incidentals
Total $(\mathbf{A}+\mathbf{B}+\mathbf{C})$

4,385

Remarks: Coding of the treatments are deciphered in Table 1. 
In general, the two types of $G$. diazotrophicus strain in the highest concentration proved to be more effective compared to the commercial control (conventional treatment used by the farmer), which allows the design of different production alternatives to the conventional ones by incorporating biotechnological products such as plantgrowth promoting microbial inoculants.

Boskovic-Rakocevic et al. (2012), when evaluating four doses of nitrogen fertilization $(0,60,120$ and $180 \mathrm{~kg} / \mathrm{ha})$ found that the content of $\beta$-carotene increased with increasing rates of nitrogen and it was found that it was statistically significant even at 120 and $180 \mathrm{~kg} / \mathrm{ha} \mathrm{N}$, compared to the control and the lowest dose of $60 \mathrm{~kg} / \mathrm{ha}$. The results of this work highlight the importance of the use of G. diazotrophicus in its highest concentration, which allowed a synergistic action with the level of fertilization applied, resulting in positive effects on crop quality and yield. In this sense, the physical-chemical and biological characteristics of the soil must be evaluated in order to guarantee the sustainability of the productive systems, as evidenced in this study, which used optimal levels of nitrogen $(0.68 \%)$ and phosphorus (89 ppm) in the soil reported in the laboratory soil analysis at the beginning of the trial, reaching the best yields in the crop cycle evaluated. However, it would be difficult to sustain this type of response over time if a proportion of nutrients equivalent to the extraction of the crop is not returned to the soil or growth promotion strategies such as the application of the bacterium G. diazotrophicus are not used in the highest concentration evaluated that demonstrated the best yields even without the addition of nitrogenous and phosphate sources.

It should be noted that although the initial phosphorus contents ( $89 \mathrm{ppm})$ in the study site are high, due to the characteristics of the soil thanks to the presence of allophane clay, there is a high retention of said element, reducing its availability for the plant. In this regard, the phosphate solubilization properties tested for $G$. diazotrophicus (Restrepo et al., 2017) make possible to avoid additional applications of phosphate fertilizers while preserving optimal crop yields and economic feasibility.

Cruz-Tobar et al. (2018), showed that carrots have a low response to nitrogen, phosphorus, potassium, and manure in soils where the main rotation crop was potatoes due to the residual effect of fertilizers applied in high doses to the crop, obtaining a second quality production. This situation was not observed in this study, despite the fact that there was a similar rotation. In addition, the use of $100 \%$ nitrogen and potassium fertilization allowed those authors to obtain a mostly first quality crop. Similarly, it was shown that the use of only G. diazotrophicus without any addition of nitrogen and phosphorus resulted in the best carrot weight (126.48 g), obtaining a very good quality harvest, as long as the nitrogen and phosphorus levels in the soil are suitable for the cultivation of this vegetable.

Regarding the production costs of the carrot crop according to the conditions of Caldas in Colombia, an investment in 115 days equivalent to the crop cycle was estimated (Table 2). The values are expressed in US dollars per hectare during the investment period. The inoculations of the native isolate $G$. diazotrophicus for the $d l$ concentration with and without the addition of nitrogenous and phosphorus fertilization were the ones with the lowest share of the harvest labor in the total costs with $28.89 \%$ and $30.55 \%$, respectively (Tables 1 and 2).

The production costs for one hectare in each of the bacterial inoculates differ until the beginning of the harvest because both the cultural tasks and the inputs used present differential costs (fertilization and labor). The main variation occurred in the labor category, specifically associated with harvesting tasks, due to the fluctuation of productivity that was evidenced in each of the evaluated treatments. Likewise, a fluctuation in inputs is evidenced due to the cost of the inoculants (Table 2). During the estimation of the total costs per hectare, the following parameters were taken into account: labor costs, supplies, and the cost of bacterial suspensions

The highest production cost (US\$ 4,390/ha) corresponded to the use of the standard strain at the $d 2$ concentration with and without fertilization with nitrogen and phosphorus (Table 2). In these treatments, the participation of labor was high in relation to total costs $(42.62 \%)$ and based on the yield obtained $(37,867 \mathrm{~kg} / \mathrm{ha})$ (Tables 1 and 2).

One of the items with the highest share in production costs for all evaluated treatments (including controls) was labor, which ranged between $45.65 \%$ and $28.89 \%$ of total production costs. Within the item of labor, cultural tasks are those with the highest participation due to the slope conditions of the terrain (eH 5\%) present in the study area, which requires that each one of the tasks is done manually. Finally, the share percentages of bacterial suspensions at the concentration of $8.8 \times 10^{7} \mathrm{CFU} / \mathrm{mL}$ have an upward behavior in production costs (labor and supplies) and a downward behavior for the harvest, taking into account that the latter is concentrated. In turn, the treatments with this concentration present a lower yield than the controls.

The carrot crop where the strain ATCC 49037 was applied at the $d 2$ concentration without nitrogenous and phosphate fertilization presents the best gross revenue (US\$ $15,208 /$ ha), followed by the treatments with application of the native isolate with and without nitrogenous and phosphate fertilization, which presented gross incomes between US\$10,000 and US\$10,500 per hectare, along with the control treatment without fertilization (Table 3). The treatments that used bacterial inoculants of $G$. diazotrophicus at a concentration of 
Table 3: Economic analysis of the carrot crop in the presence of G. diazotrophicus with and without nitrogen and phosphate fertilization under the conditions of Caldas (Colombia)

\begin{tabular}{|c|c|c|c|c|c|c|c|c|c|}
\hline \multirow{2}{*}{ Treatment } & \multirow{2}{*}{$\begin{array}{c}\text { Production } \\
\text { costs } \\
\text { (US\$/ha) }\end{array}$} & \multicolumn{4}{|c|}{ Revenue per quality (US\$/ha) } & \multicolumn{2}{|c|}{ Revenue (US\$/ha) } & \multirow{2}{*}{$\begin{array}{c}\text { UPM } \\
\text { (US\$/kg) }\end{array}$} & \multirow{2}{*}{$\mathrm{B} / \mathrm{C} \mathbf{R}$} \\
\hline & & Extra & First & Second & Third & Gross & Net & & \\
\hline Control-0NP & 3,645 & 1,448 & 6,967 & 1,458 & 579 & 10,453 & 6,807 & 0.13 & 1.87 \\
\hline Control-100NP & 3,961 & 1,309 & 4,636 & 2,813 & 539 & 9,297 & 5,336 & 0.14 & 1.35 \\
\hline ATCC- $d 2-0 \mathrm{NP}$ & 4,390 & 7,358 & 6,377 & 0 & 1,472 & 15,208 & 10,817 & 0.12 & 2.46 \\
\hline GIBI- $d 2-0 N P$ & 4,072 & 3,009 & 2,608 & 3,210 & 1,204 & 10,031 & 5,959 & 0.13 & 1.46 \\
\hline ATCC- $d 2-100 \mathrm{NP}$ & 4,335 & 2,984 & 2,586 & 3,183 & 1,194 & 9,946 & 5,611 & 0.14 & 1.29 \\
\hline GIBI- $d 2-100 N P$ & 4,385 & 3,107 & 2,693 & 3,314 & 1,243 & 10,357 & 5,972 & 0.14 & 1.36 \\
\hline ATCC- $d 1-0 \mathrm{NP}$ & 3,715 & 0 & 2,586 & 3,556 & 889 & 7,031 & 3,316 & 0.15 & 0.89 \\
\hline ATCC- $d 1-100 \mathrm{NP}$ & 3,998 & 0 & 5,628 & 1,155 & 866 & 7,648 & 3,650 & 0.17 & 0.91 \\
\hline GIBI- $d l-0 N P$ & 3,424 & 0 & 1,454 & 895 & 2,013 & 4,361 & 937 & 0.19 & 0.27 \\
\hline GIBI- $d 1-100 N P$ & 3,815 & 0 & 1,644 & 1,012 & 2,277 & 4,933 & 1,118 & 0.19 & 0.29 \\
\hline
\end{tabular}

UPM: unit production margin; B/C R: benefit/cost ratio.

$8.8 \times 10^{7} \mathrm{CFU} / \mathrm{mL}$, regardless of whether or not they have nitrogenous and phosphate fertilization, are the ones with the lowest yield and, consequently, those that exhibit the lowest gross income, making them financially unattractive.

The lowest unit production margin $(0.12 \mathrm{U} \$ / \mathrm{kg})$ was obtained for the treatment with the strain ATCC 49037 applied at the high level of concentration $\left(18 \times 10^{7} \mathrm{CFU} /\right.$ $\mathrm{mL}$ ) without fertilization, while the UPM of the commercial control (farmer's conventional treatment with $100 \%$ fertilization) was US\$ $0.14 / \mathrm{kg}$. This constitutes a competitive advantage for the farmer who decides to apply G. diazotrophicus as a growth promoter, due to the fact that having a low UPM, considered as the minimum value at which the farmer can sell the product in the market to recover the investment (constituting the equilibrium point) and having a low price, the producer will have more opportunities to market it, without presenting direct competition with other producers (Table 3). In this way, the estimated UPM values that were below US $\$ 0.14 / \mathrm{kg}$ present an equilibrium point suitable for an adequate profit margin in the production system. Within this range, the bacterial suspensions of both strain types with concentrations of $18 \times 10^{7} \mathrm{CFU} / \mathrm{mL}$ with and without the nitrogenous and phosphate fertilization are found. The bacterial suspensions with concentrations of $8.8 \times 10^{7} \mathrm{CFU} / \mathrm{mL}$ presented higher values in the UPM of US\$ $0.17 / \mathrm{kg}$, which is equivalent to the value perceived in the market for the product, making these introductions financially unviable (Table 3).

According to the benefit/cost ratio calculated by the adopted assessment (Table 3), the bacterial suspensions applied at high concentrations with and without the nitrogenous and phosphate fertilization showed the highest profitability along with the control treatment without fertilization, standing out as financially attractive for an investor in this type of production system. On the other hand, the bacterial suspensions applied at low concentra- tion do not exceed the investors' perspectives, making the profitability of the crop unfeasible. For the benefit/cost ratio, the treatment with the use of the standard strain at a concentration of $d 2$ without fertilization presented the highest B/C R (for every dollar invested, the farmer receives US\$2.46 gross), followed by the treatments with this same concentration for the native isolate without fertilization and the standard strain with nitrogenous and phosphate fertilization (see Table 3). The lowest relationships were reported again for the treatments with the isolate GIBI029 at the $d 1$ concentration without and with fertilization $(0.27$ and 0.29 , respectively).

\section{CONCLUSIONS}

The use of the diazotrophic bacterium G. diazotrophicus (standard and native strains) in suspensions with concentrations of $18 \times 10^{7} \mathrm{CFU} / \mathrm{mL}$ in carrot crops makes possible to significantly improve their economic feasibility, reaching yields of up to $37,417 \mathrm{~kg} / \mathrm{ha}$, even in the case of no addition of nitrogenous and phosphate fertilizers, as long as the soil contains the required levels of these nutrients.

The results obtained in this work indicate that benefit/ cost ratios higher than 1.46 and net income of up to US\$ 10,817/ha can be achieved. In particular, the possibility of using the Colombian native isolation GIBI029 of $G$. diazotrophicus in an economically efficient way was demonstrated in the search for more sustainable and competitive cultural practices.

\section{ACKNOWLEDGEMENTS, FINANCIAL SUPPORT AND FULL DISCLOSURE}

The authors would like to thank the Colombian Ministry of Science, Technology and Innovation, Minciencias (grant 112752128333), the Vice-Rectorate of Research and Graduate Studies at the Universidad de Caldas, and the 
Research Direction at the Universidad Católica de Manizales for funding this work in the framework of the research project "Production and assessment of a growth promotor for tomato and carrot crops based on Gluconacetobacter diazotrophicus". The authors declare that they have no conflict of interest carrying the research and publishing the manuscript.

\section{REFERENCES}

Agronet (2020) Cifras Agropecuarias. Available at: http:// www.agronet.gov.co/Paginas/estadisticas.aspx. Accessed on: January $16^{\text {th }}, 2020$.

Ahmad I, Altaf MM, Sharma J \& Al-thubiani AS (2016) Diversity, Quorum Sensing, and Plant Growth Promotion by Endophytic Diazotrophs Associated with Sugarcane with Special Reference to Gluconacetobacter diazotrophicus. In: Choudhary D, Varma A \& Tuteja N (Eds.) Plant-Microbe Interaction: An Approach to Sustainable Agriculture. Springer, Singapore. p.1-23.

Arbelaez L, Rivera J, Hurtado-Salazar A \& Ceballos-Aguirre N (2016) Technical and Economic Evaluation of Three Types of Tomato Nutrient Solutions under Semi-Controlled Conditions. Journal of Agricultural Science, 8:68-78.

ATCC (2020) Search by Keyword. Available on: https:// www.atcc.org/search\#q=Gluconacetobacter\%20diazotrophicus\&sort=relevancy. Accessed on: January 16 2020.

Beneduzi A, Moreira F, Costa PB, Vargas LK, Lisboa BB, Favreto R, Baldani JI \& Passaglia LM (2013) Diversity and plant growth promoting evaluation abilities of bacteria isolated from sugarcane cultivated in the South of Brazil. Applied Soil Ecology, 63:94-104.

Boskovic-Rakocevic L, Rados P, Jasmina Z, Milan Z, Nenad P \& Milena D (2012) Effect of nitrogen fertilization on carrot quality. African journal of agricultural research, 7:2884-2900.

Corabastos (2020) Precio Promedio Anual por Producto. Available at: https://www.corabastos.com.co/index.php/features/serviciosweb/historico-de-precios. Accessed on: January $20^{\text {th }}, 2020$.

Cruz-Tobar E, Vega-Chariguamán J, Albán A, Gonzalez M, SaltosEspín R \& González-Rivera V (2018) Aplicación de abonos orgánicos en la producción de zanahoria (Daucus carota L.). Revista de Investigación Talentos, 5:26-35.

DANE (2017) Características relevantes en el cultivo de la zanahoria (Daucus carota L.) en Colombia y estudios de caso sobre costos de producción en los municipios de Madrid (Cundinamarca) y Ventaquemada (Boyacá). Available at: <https:/ /www.dane.gov.co/files/investigaciones/agropecuario/sipsa/ Bol_Insumos_jun_2017.pdf. Accessed on: July 24 $4^{\text {th }}, 2020$.

Dibut B, Martínez R, Ríos Y, Plana L, Rodríguez J, Ortega M \& Tejada G (2010) Estudio de la asociación Gluconacetobacter diazotrophicus-viandas tropicales en suelo ferralítico rojo. I. selección de cepas efectivas para la biofertilización de boniato, yuca y malanga. Cultivos Tropicales, 31:51-57.

Eshaghi E, Nosrati R, Owlia P, Malboobi MA, Ghaseminejad P \& Ganjali MR (2019) Zinc solubilization characteristics of efficient siderophore-producing soil bacteria. Iran J Microbiol, 11:419430 .

Faostat (2020) Crops. Available at: http://www.fao.org/faostat/ en/\#data/QC. Accessed on: July 24 ${ }^{\text {th }}, 2020$.

Fernández-Delgado J, Abad-Rodríguez EM \& Salgado-Pulido JM (2019) Efecto de Gluconacetobacter diazotrophicus en el cultivo del tomate (Solanum lycopercicum L.). Avances, 21:264275
Ferreira CMH, Helena MVM, Soares E \& Soares V (2019) Promising bacterial genera for agricultural practices: An insight on plant growth-promoting properties and microbial safety aspects. Science of the Total Environment, 682:779-799.

Figueroa-Viramontes U, Delgado JA, Cueto-Wong JA, NúñezHernández G, Reta-Sánchez DG \& Barbarick KA (2011) A new Nitrogen Index to evaluate nitrogen losses in intensive forage systems in Mexico. Agriculture, Ecosystems \& Environment, $142: 352-364$.

Herrera H, Hurtado-Salazar A \& Ceballos-Aguirre N (2016) Estudio técnico y económico del tomate tipo cereza élite (Solanum lycopersicum L. var. cerasiforme) bajo condiciones semicontroladas. Revista Colombiana de Ciencias Hortícolas, 9:290-300.

Paredes-Villanueva JJ, Rosario JL, Urcia-Pulido MM \& ZavaletaArmas, JC (2020) Plant growth promoter collection of Gluconacetobacter diazotrophicus from the northern coast of Peru. Scientia Agropecuaria, 11:15-21.

Restrepo GM (2014) Obtención y evaluación de un preparado líquido como promotor del crecimiento de cultivos de tomate (Solanum lycopersicum L.) empleando la bacteria Gluconacetobacter diazotrophicus. PhD Thesis. Universidad de Caldas, Manizales. $155 \mathrm{p}$.

Restrepo GM, Sanchez OJ, Marulanda, SM, Galeano NF \&Taborda G (2017) Evaluation of plant-growth promoting properties of Gluconacetobacter diazotrophicus and Gluconacetobacter sacchari isolated from sugarcane and tomato in West Central region of Colombia. African Journal of Biotechnology, 16:16191629.

Sadeghi K \& Khodakaramian G (2020) Characteristics and Ice Nucleation Activity of Sugarcane Epiphytic and Endophytic Bacteria and Their Role in Host Frostbite. Sugar Tech, 22:291302 .

Santos SG, Chaves VA, Ribeiro FS, Alves GC \& Reis VM (2019) Rooting and growth of pre-germinated sugarcane seedlings inoculated with diazotrophic bacteria. Applied Soil Ecology, 133:12-23.

Silva M, Souza MS, Oliveira IB, Daniel O, Santos SA, Marques MR \& Silva WM (2016) Influence of Flood Areas on the Number of Diazotrophic Bacteria from Pasture Grasses. Applied Ecology and Environmental Sciences, 4:84-88.

Szel'19-Sikora A, Sikora J, Niemiec M, Gródek-Szostak Z, KapustaDuch J, Kuboñ M, Komorowska M \& Karcz J (2019) Impact of Integrated and Conventional Plant Production on Selected Soil Parameters in Carrot Production. Sustainability, 11:5612.

Universidad de Caldas (2014) Sistema de Granjas - Granja Tesorito. Available at: http://www.ucaldas.edu.co/portal/?s=sistema+granjas \& $x=0 \& y=0$. Accessed on: July $24^{\text {th }}, 2020$.

Vejan P, Abdullah R, Khadiran T, Ismail S \& Nasrulhaq Boyce A (2016) Role of Plant Growth Promoting Rhizobacteria in Agricultural Sustainability - A Review. Molecules, 21:573. 